\title{
Beckett and Disability Biopolitics: The Case of Cuchulain
}

\author{
Siobhán Purcell \\ Independent Scholar
}

Copyright (c) 2019 by Siobhán Purcell. This text may be archived and redistributed both in electronic form and in hard copy, provided that the author and journal are properly cited and no fee is charged for access.

\begin{abstract}
In his depiction of the hero Cuchulain, Samuel Beckett interrogates how disability and compulsory able-bodiedness are foundational myths for the Irish Free State. Taking the interpolation of disability in biopolitics, this essay examines the normalising impulses in revivalist literature and criticism, exemplified by Lady Gregory, Standish O'Grady, WB Yeats and Daniel Corkery. Against this normalising, nationalising literature, I situate Beckett's satirical renderings of Cuchulain in "Censorship and the Saorstat" and Murphy, as evidence of a profound discomfort and frustration with the biopolitical mechanisms of governance in the newly-founded Irish State.
\end{abstract}

Key Words. Beckett, Biopolitics, Ireland, Disability, Cuchulain

Resumen. En su retrato del héroe Cuchulain, Samuel Beckett cuestiona cómo la discapacidad y la obligatoriedad de la integridad física constituyen aspectos fundacionales del Estado Libre Irlandés. Teniendo en cuenta la relación de la discapacidad con la biopolítica, el presente ensayo examina las tendencias normalizadoras en la crítica y literature del renacimiento irlandés con autores tales como Lady Gregory, Standish O'Grady, WB Yeats y Daniel Corkery. Dentro de este marco literario de naturaleza normalizadora y nationalista situaré los retratos satíricos que Beckett realiza sobre Cuchulain en los textos "Censorship and the Saorstat" y Murhpy. Dichas representaciones son evidencia de una profunda frustación y disconformidad con los mecanismos biopolíticos de gobernanza en el entonces incipiente Estado Irlandés.

Palabras clave. Beckett, biopolítica, Irlanda, discapacidad, Cuchulain

\section{The Political Anatomy}

Throughout Beckett's works, the human body is subject to constraints, violence and governance. His works reveals the contingent workings of the human form, and display a 
profound mistrust of reproduction. This mistrust is often rendered in terms of disability; indeed, it is the nature of these impairments that often determines the action of the narrative. Given the significant social and political upheaval in which Beckett wrote, an examination of these features of his writing from the perspective of disability and biopolitics is entirely fitting. In Discipline and Punish, Foucault identifies and traces the social forces that act upon the human body. The very idea of the human body having skills or being improvable came at a precise historical moment, at which time, what was formed was "a policy of coercions that act upon the body, a calculated manipulation of its elements, its gesture, its behaviour" (137). Foucault explores how in this moment, the human body entered a "machinery of power that explores it, breaks it down and rearranges it" (137). This gives rise to what he terms a "political anatomy", that is, a defining of how "one may have a hold over others' bodies, not only so that they may do what one wishes, but so that they may operate as one wishes, with the techniques, the speed and efficiency that one determines" (137). He thus concludes that discipline which produces "subjected and practiced bodies, "docile" bodies" (138).

This analysis of institutional powers - prisons, hospitals, schools - which discipline the human form, led Foucault to reconceptualise power in its effects on the human body. Foucault defined biopolitics in his lectures at the Collège de France as "a technology of power that consists in techniques, practices, and procedures that are aimed at organising, regulating, and governing the phenomena peculiar to life in the context of population" ("Society" 24647). These biopolitical practices, arranged and administered by the state, work upon the bodies of that population, mainly operating through what Foucault termed "biopower", that is, a modern technology of population management through the regulation of death, birth, reproduction and illness. The role of the state is the administration and application of biopower is extensive. Foucault traces the etymology of "governance" beyond mere "government"; rather, governance encompasses the myriad forces and constraints that act upon the individual's body to render it "docile". For Foucault, government acts as "the conduct of conduct"; that is, it subtly and multifariously acts upon citizens as a force for order (qtd. in McRuer 21).

Taken together, the notions of docility, discipline, governance, population, and conduct, which Foucault identifies, sets out an imagine of the human body as subject to and inhibited by a wealth of productive constraints which act upon it. Latent within this idea then of a docile body is the notion of disability. Foucault's examination of the structures of power that govern the human body. Foucault does not examine disability at any great length, perhaps because the structures he examines are those which conjure the category of experience which we call disability into existence. Disability in the contemporary understanding only comes into being because of the disciplinary forces and subjection of imposed bodies "a relation of docility-utility" (Discipline 137). As Rob McRuer has it, it is only since the late $18^{\text {th }}$ century that bodies have begun to be monitored by "disciplinary institutions and by increasingly compulsory self-policing) for signs of behavioural and physical difference that might impede their productivity" (McRuer 21).

There is richness to the Foucauldian analysis of disability that illustrates not only the importance of Foucault for disability studies, but of disability studies for studies of Foucault and the human sciences generally. For Shelley Tremain: "the category of impairment emerged, and in many respects, persists in order to legitimize the governmental practices that generated it in the first place" (Foucault 11). Central to these acts of legitimising or disqualification, concept of the "norm" is of fundamental significance to biopolitics and biopower; as Tremain argues, "[a]s a governmental rationality which aims to increase its efficiency by harnessing the vagaries of life, biopower normalizes people in order to make them governable" (Tremain, "Bioethics" 102). Tremain's identification of the norm and the 
correlative "other" required to identify it sets out a model of legitimate experience that is not pathological and those bodies outside of the strictly governed norms are subject to exclusion.

\section{A Normal, National Literature}

Samuel Beckett's literary career - so often celebrated for pushing traditional ideas of form and representation beyond all previous benchmarks - was forged, on one hand, in the wake of literary modernism, and on the other, in the burgeoning cultural conservatism of the Irish Free State. Beckett's early critical pieces are interrogative works of social commentary that rail against the policies of the Irish Free State, suggesting that Foucault's analysis of normalisation is applicable to literary studies too. In these critical essays, Beckett troubles the coercive conservative consensus in Irish sexual politics. In an early polemic, "Che Sciagura", published in the 1929 TCD Miscellany, he decries the crackdown on contraception and the "uncompromising attitude [of] the Catholic Truth Society" (42). In "Recent Irish Poetry" (1934), he laments the class of (mostly) revivalist poets, in their conservative fixity to tradition: a crowd of pullulating thermolaters who "adore the stuff of song as incorruptible, uninjurable and unchangeable" (Disjecta 70). Beckett's image of "pullulation" (rapid breeding) speaks to a spawning middle class who do not engage intellectually or critically. The literary classes refuse to explore "rupture in the lines of communication" (Disjecta 70).

In this fear, Beckett was not alone. It was shared by many of his fellow contemporary authors - Yeats, Synge, Lady Gregory, Joyce - all of whom express agitation with the middle classes in Ireland. Against such a tradition, influential works such as Daniel Corkery's Synge and Anglo-Irish Literature were gaining ground. In this 1931 work, Corkery, an outspoken nationalist, outlined the tenets of a national literature in explicitly normative terms:

It is therefore not normal, for a normal literature while welcoming the criticism of outsiders neither lives nor dies by such criticism. It abides the judgement of its own people, and by that judgement lives or dies. If this literature then be not a normal literature it is not a national literature, for normal and national are synonymous in literary criticism. (2)

Corkery's insistence that a national literature must be "normal" makes the connection between nationalism and prescriptive normativity explicit. While he decries the homogeneity of the received Anglo-Irish canon, he nevertheless presents an utterly homogenised putative native stock that must find new paths to literary representation. He continues his attack on those Anglo-Irish literary figures that left Ireland with another bodily metaphor describing expatriation as a "chronic disease" among Anglo-Irish authors (6). He argues that the tradition of Anglo-Irish literature deriving from Goldsmith, Sheridan, Burke, Moore, Wilde, Shaw, Joyce, Moore is not "indigenous" and the moulds and norms of which were fashioned by

writers who did not labour for their own people. ... Its moulds therefore cannot have been fashioned to express the genius of Ireland in the English language. If in later years certain writers tried to do this, as some have tried, the unnatural homogeneity of these moulds proved their greatest enemy, so inflexible they have ever been. (Corkery $6)$.

Ethnic racism is the lynchpin of Corkery's argument, since his prescription for "indigenous" exceptionalism implies the racial otherness of non-Ascendency writers. Echoing eugenicist writers such as Francis Galton, Corkery underscores this with reference to their "genius". For Corkery, English-language models are utterly useless to the expression of Irish genius, which 
is both native and innate. While Beckett does not explicitly address Corkery's argument, they shared a literary milieu, and he was aware of the conservative impulse. For John Harrington, Beckett's early prose works, in particular More Pricks Than Kicks, were forged with this cultural normativity firmly in mind (52). Corkery's attempts to normalise/nationalise the Irish literary canon is an act analogical to biopolitical governance: it seeks to "make Irish literature live while letting Anglo-Irish literature die". Corkery pushes for a normative ideal of native sameness and linguistic authenticity. Where Corkery emphasised a literature that was above all else, 'normal', Beckett's earliest critical pieces scorned such an idea.

The reconstituted revivalist myths of blood-sacrifice and of disability were of critical importance to the symbolism and romanticism of the formation of the Irish State. Emblematised by Matthew Arnold's discussion of the Celtic feminine, as Marion Quirici describes. "the language [Arnold] used to convey the barbarism and the inherent incapacities of the Celtic race was that of disability: lameness, emotional imbalance and insanity" (77). Nineteenth century discussions of "Celtic" bodies were often couched in the language of racialised disability and there was a growing preoccupation with stereotypes of "Celtic" populations as racially degenerate. This association of the Celtic body with disability and lameness inflects the foundational myths that represent a new type of Irish body. As Quirici has demonstrated, Yeats and Lady Gregory's Cathleen ni Houlihan epitomises this examination of the body politic and couches it squarely in terms of impairment and disability. Tracing the halting first steps of the Shan Van Vocht who transforms into a young woman "with the walk of a queen", for Quirici, Cathleen ni Houlihan is "a performance of regeneration and rehabilitation" (79), exploring the blood sacrifice of young bodies - and minds - laid down willingly in service of the state. Yeats and Lady Gregory's play thus conforms exactly to Corkery's vision for here the "normal" and the "national" are mutually constituting, each relying on the other for its integrity.

\section{"Censorship in the Saorstat"}

By contrast, Beckett's critical works from this time take a very difference perspective. At the request of The Bookman, Beckett wrote "Censorship in the Saorstat" in August 1934. That same month, he left London to return to Dublin, writing to McGreevy: "difference between the cities: Dublin consumes one's impatience, London one's patience" (Letters I 217). There is great restlessness in Beckett's letters from this time. Dublin is a literary wasteland: "[w]ith no papers, and all the journalists creeping about miserably, or filing mountains of copy that will never become public, Dublin is at her humanest" (Letters I 218). Beckett's sardonic personification of Dublin yokes both meanings of the word "humanest"; Dublin is at once capable of great compassion while, at the same time, quashing the literary impulse in a perversion of the civilizing process. Dublin, oppresses, literally: acting upon the very bodies of its citizens, it forces journalists and writers to creep about miserably. Beckett, too, found himself "creeping along genteel roads on a stranger's bike" (Letters I 125).

It is no surprise then that in fewer than five incandescent pages, "Censorship and the Saorstat" pillories the state's intrusion upon public discourse, in the form of the Censorship of Publications Act, 1929. The Act legislated against the publication, printing, or procurement of "indecent matter", to include "medical, surgical or physiological details", the publication of which would be calculated to injure public morals. Works found to be indecent, defined by the Act as "suggesting of, or inciting to sexual immorality or unnatural vice or likely in any other similar way to corrupt or deprave" would be added to "The Register of Prohibited Publications", a swelling list of scintillating interest policed by "five fit and proper persons" appointed to their role by the Minister for Justice. The Act was successful in suppressing materials relating to family planning; by 1934, eight of the first twelve publications listed as 
prohibited were by Margaret Sanger and Marie Stopes, and all pertained to parenthood and birth control. In "Censorship in the Saorstat", Beckett attacked this conservatism:

For the Irish are a characteristic agricultural community in this, that they have something better to do than read and that they produce a finished type of natural fradeur having nothing to learn from the nice discriminations of Margaret Sanger and Marie Carmichael Stopes, D. Sc., Ph. D., F. R. S. Litt,, etc. (Disjecta 87).

In his essay, Beckett takes the wording of the 1929 document and meticulously undermines its legitimacy. Beckett quotes from the Act extensively throughout the piece, mimicking the four-part structure of the Act itself. "The Board shall consist of five fit and proper persons," writes Beckett, of which "'Fit and proper' would seem to denote nothing less than highly qualified in common sense, 'specialists in common sense' (Dep. Prof. Alton)" (Disjecta 85). The qualifying attributes of the Board members as "fit and proper", rife with Darwinian undertones, are rightly shown to be highly ambiguous. Remembering that this board is working for the common "class of reader in Saorstat Eireann" and dealing directly with the implications of literature on common morality, the implications of appointing "fit and proper" persons to govern an entire nation, reveals the inherently paradoxical premise of the Act. The Act privileges "fitness" yet suppresses those works that may be seen to broaden the minds of the Irish citizenry.

Part IV of the Act, the section of most interest to Beckett, titled "Miscellaneous and General", aimed to oppress those works which:

advocat[e] or which might reasonably be supposed to advocate the unnatural prevention of conception or the procurement of abortion or miscarriage or any method, treatment or appliance to be used for the purpose or such prevention or such procurement (6.1)

With tongue firmly in cheek, Beckett pronounces that:

France may commit race suicide, Erin will never. And should she be found at any time deficient in Cuchulains, at least it shall never be said that they were contraceived. Thus to waive the off chance of a reasonable creature is no longer a mere mortal sin but a slapup social malfeasance, with corollary in the civic obligation to throttle reason itself wherever it happens to be 'flung' in to a form obnoxious to the cephalopods of state. The pure Gael, drawing his breath from his heels, will never be permitted to defile his mind with even such fairly clean dirt as the Black Girl in her Search for God so long as he can glorify his body to the tune of half a dozen byblows, white as pthisis, in search for a living. (Disjecta 86-87)

In this extended passage, Beckett links the literary ideal of the "pure Gael" to nationalistic idealism, population concerns, and the state's collusion in governing its citizens' bodies. The "obnoxious" forms that so offend the "cephalopods" in power are not just benign works of literature but signify the state's intention to homogenise the religious, political and racially disparate populations in the country. With his reference to "race suicide", the complexities and nuances of Beckett's own position comes to the fore. While Ireland prohibited eugenic literature, ostensibly an anti-eugenics position, much of the "racial" rhetoric that accompanied the founding of the Irish Free State was explicitly eugenic in tone. The Act's biopolitical intrusion upon both the sexual and literary lives of the Irish citizenry is shown to be completely lacking; an act against reason itself. 
As Seán Kennedy has written: "[f]or Beckett, the most important impact of the Catholic Church in Ireland was its sponsorship of repressive measures aimed at extending its power over a newly enfranchised Irish citizenship" and this mattered more than "liberation from enslavement to English culture" ("MacGreevy" 198). Beckett is wary of oppressive measures that privilege Catholic ideology at the expense of personal or religious freedom. Beckett's sarcasm reveals the insolence of an act that aims to preserve the sanctity of the Irish body at the expense of the education of the Irish mind. Beckett explicitly targets the revivalist rhetoric of health and strength built into the establishment of the Irish Free State and the Gaelic Athletic Association, and the internal paradox of a movement that would seek to address and govern the health of the nation at the expense of all other concerns. The Act seeks to preserve, but also to keep out, some of the tenets of eugenic thinking, highlighting the biopolitical force of the Censorship Act for it gives us a sterilized state, over-populated and under-nourished: inured to the need for family planning and adequate contraception.

Beckett's shows the farcical distinction that upholds the Free State attitude: the culture it advocates, while in part born of fears of degeneration, denies the means to control regeneration. The Ireland of "Censorship in the Saorstat", as depicted by Beckett, is a discriminating regime that unwittingly discriminates against the very works that uphold its own model of the "fit and proper" person. In a final rhetorical flourish, Beckett's dark concluding passage, "[w]e now feed our pigs on sugarbeet pulp. It is all the same to them", gets to the heart of the paradoxical stance of the Act, and the Saorstat more generally, conflating the hegemonic discourses of a Catholic morality aimed at upholding the dignity of the Gaelic body while rejecting literature aimed to that effect (Disjecta 88).

\section{Purely Fantastic, Unmodern, Ideal, Breezy, Spring-dayish Cuchulanoid National Theatre}

Beckett's particular beef with Cuchulain targets the revivalist reconstruction of this mythical figure, in particular. The revivalist Cuchulain, epitomised in Standish O'Grady and in Lady Gregory's Cuchulain of Muirthemne, is sanitised of the more troubling dimensions of his portrayal in the Táin, constraining him to English models of gentlemanly heroism (Valente). For Pearse, Cuchulain was a literal "ideal"; as he wrote in An Claidheamh Soluis $27^{\text {th }}$ October 1906:

Our first counsel to Gaels, let them always have before them a noble goal, an 'ideal' as the English speaker would say. Let us remember Cú Chulainn. Let his deeds and sayings or the deeds and sayings of some other hero like him be a guiding light shining gloriously in the sky before us. (Pearse)

The potency of Cuchulain as a national figure inheres in the dignity of his intention, his disciplined appeal to power, making him the symbol of a noble yet governable Ireland. For Synge, the dramatic potential of harnessing his great power was such that it might save a version of Irishness; as he wrote to his friend Stephen McKenna, "the stage might regenerate Ireland, used Cuchulainly" (in Green and Stephens 157). While Yeats introduces Lady Gregory's account of Cuchulain by praising her ability to shape the narratives which she hears, to take their constituent, inharmonious parts and to order them; "[s]he has already put a great mass of stories, in which the ancient heart of Ireland still lives, into a shape at once harmonious and characteristic" (Yeats, "Preface" viii). The adoption of Cuchulain and elision of his monstrous features is a normalising act; depathologising Cuchulain represents an act of making Ireland whole.

Valente reads the revivalist adoption of the Cuchulain myth as a reiteration of the 
English tradition of manly virtue. The revivalist myth celebrates "someone who channels the ferocity expected of the elite warrior into a strenuous discipline and dutifulness, born of an allegiance to an agnostic code of honour" (142). As Valente shows through a sustained reading of the ambiguities of Cuchulain's character, the revivalists reduce many of the tensions of the original. For Valente, "in portraying the Gaelic warrior as an apotheosis of chivalry, the revivalist translators had not only to sanitize the details of the Táin but also to mistake its governing point of view and hence its guiding purport" (150). In mistaking - or rewriting - what Valente terms the "governing" point of view, the revivalist "selectively moralises" and does so in keeping with the "prerogatives of revolutionary nationalism" (150). Occluding Cuchulain's physical differences reveals the normalising nationalising ethos; his superhuman powers are restrained in the revivalist accounts that elide the less savoury and less governable tracts of his character.

In particular, the superhuman rage, or riastrad translated by Thomas Kinsella as "warp spasm" which describes Cuchulain murderous rage, drives him to unspeakable acts of war. The ríastrad dehumanises Cuchulain; he is rendered monstrous, distorting his physical form and rendering him capable of senseless violence:

The first warp-spasm seized Cúchulainn, and made him into a monstrous thing, hideous and shapeless, unheard of. His shanks and his joints, every knuckle and angle and organ from head to foot, shook like a tree in the flood or a reed in the stream. His body made a furious twist inside his skin, so that his feet and shins switched to the rear and his heels and calves switched to the front. (Kinsella 150)

Cuchulain is a shape-shifter - a tenth-century Incredible Hulk - a figure of disability and a potent and visceral depiction of the powerful interplay between body and mind in the premodern era. All of this is quenched in Lady Gregory's sanitised version. Her works, and the revivalist reimagining of Cuchulain thus represents an act of governance; governance of the potent, tangible biopower that Cuchulain's unbridled physicality represents. In Cuchulain of Muirthemne, in Standish O'Grady's works, in Pearse's vision of the "ideal", Cuchulain, named for a dog, is brought to heel in the service of state-authored versions of acceptable autonomy and idealism. Lady Gregory's ability to normalise the figure of Cuchulain anticipates Corkery's insistence that what is normal is national, and to the four winds may the rest be scattered.

This tension between the original portrayal of Cuchulain, and Lady Gregory's considerably more sanitised version, becomes a highly motivating force in Yeats' early play On Baile's Strand. In this play, Cuchulain's monstrous shape-shifting abilities are sublimated; he is a statesman and a leader, locked in negotiations with his ministry, represented by the old Kings and Conchubar in particular. The biopolitical force in the play manifests in Conchubar's manipulation of Cuchulain and the repeated and insistent emphasis on lineage, heritage and reproduction; Conchubar questions the Young Man about his nobility before revealing the fact of Cuchulain's own misfit with governance:

Once the Young Man has been slain, the true

And you for all the wildness of your blood

And though your father came out of the sun

Are but a little king and weigh but light

In anything that touches government,

If put into the balance with my children (256)

Indeed, the tragedy of the work derives from Cuchulain's age, and the fact of his 
disengagement from the youth and vitality of his company; it is Cuchulain's "barren and restless" nature that seals his son's fate (Yeats, Manuscript xxix). As Kiberd, Valente and Bixby ("Cuchulain") have shown, Yeats deploys Cuchulain as national emblem, a figure that mirrors Cathleen ni Houlihan in epitomising the body politic. Kiberd reads Yeats's play as a national epic, which posits the emerging middle-class Catholic elite against the romantic and heroised Anglo-Irish pride, concluding that the play "foretold the early history of the Irish state as yet another narrative of usurpation, in which imagination and vitality would make way for a dreary, administrative guile" (270).

While the "high" action of the play takes place between the characters of Cuchulain and Conchubar, the play begins, and ends, with two disabled characters: the Blind Man who leads, and the Fool who is led. The interactions of the pseudo-couple symbolise the larger themes of the work; where Cuchulain is the fool, Conchubar is blind reason (Yeats, Manuscript xxix). Yeats' explicit portrayal of two disabled characters illustrates a host of symbolic inferences about the nature of disability. Like Cathleen ni Houlihan, it uses ableist tropes to frame a story of national regeneration. Nevertheless, Yeats' play also shows biological forces as powerfully motivating factors and demonstrates the hungry plight of those marginalised from society's care. The effect of this disempowerment is devastating, causing the great tragedy to come to pass. Years later, in Yeats' last play, The Death of Cuchulain, Cuchulain dies at the hands of the same blind character.

The symbolic force of Yeats' staging of disabled characters to stage myths of national regeneration is dubious, yet has an enduring legacy. Beckett uses the disabled pseudo-couple of Yeats' On Baile Strand in a number of later plays, including in the complex co-dependency of couples in Waiting for Godot, Endgame and Rough for Theatre II, but Beckett also responds to the troubling biopolitics of Yeats' play in his critical reflections of the revivalist Cuchulain in his novel Murphy. In Beckett's account, we encounter a very different and altogether more challenging view of this vestige of the 1916 Easter Rising. Beckett took Oliver Sheppard's The Death of Cúchulainn, installed in the General Post Office in 1935 to commemorate the Easter Rising, as the site for his Cuchulainoid satire. Here, we encounter a very different and altogether more challenging view of this vestiges of the 1916 Rising. The statue that so confounds Neary is Oliver Sheppard's of the dying Cuchulain, designed and modelled in 1911-12, but installed at the behest of Eamonn De Valera in the General Post Office on April 21 $1^{\text {st }}, 1935$. De Valera described the work as a "beautiful piece of sculpture, the creation of Irish genius, symbolising the dauntless courage and abiding constancy of our people" (Dedication of the Cuchulain statue at the Dublin GPO, 1935). Pearse's idealisation of the Cuchulain Gael was instrumental in the self-mythologising of the Irish Free State. The state, the idealised body, blood sacrifice and the service of the nation's young generations foot soldiers born and bred of Ireland - here coalesce in Beckett's scathing account. His contempt for thin idealised standards of heroic and nationalist beauty are countered in his own artworks by characters who reject and stand in opposition to such normative ideals.

With Murphy, Beckett inserts himself into the material history of the event, summoning his own Cuchulain in a novel that points to the difficult heroic idealism of the Irish Free State. Beckett contrasts the virulent heroism of both Pearse and Yeats' visions of Cuchulain in the GPO and offers instead a ludicrous check of the idealistic heroism that shaped the mythology of the Rising itself and informed the politics of the 1930s Free State. Neary's encounter with the Cuchulain statue is tinged with religious reverence: "Neary had bared his head, as though the holy ground meant something to him" (Beckett, Murphy 29). The cultic revivalist reverence of Cuchulain and the nationalist celebration of self-sacrifice is here taken to a logical extreme; yet for all the glory of blood sacrifice, Neary's attempt to martyr himself belies the state's intolerance of any reverence that falls outside of the statesanctioned norm. Neary's assault on the shrine represents an interruption of the untrammelled 
flow of revivalist Cuchulanoid propaganda. The very idea of Neary dashing his head against the statue's buttocks is plainly ridiculous; as Sheppard depicts a Christ-like Cuchulain in the act of tying himself to a standing stone that my might die a heroic death on his feet. The very fact of the statute having only an implied set of buttocks derides Neary's attempted act of selfsacrifice.

Neary's foil, the civic guard represents the lumbering behemoth of the State, a guardian of civil obedience and docility. Alerted to the possibility that he has apprehended a vandal in the act, the guard approaches Neary with his baton drawn. The symbol of sovereign rule and of state-sanctioned violence, the guard is described as nobly proportioned but somewhat dull and unreflective, unable to think outside the script provided in "any branch of his training" or to issue even issue simple advice as to express such independence of thought, "to plunge into the labyrinths of an opinion" would "tax his ability to the utmost (Beckett, Murphy 29; 30). The guard is the foot soldier of the state's apparatus; large and imposing yet inarticulate and incapable of free thought. Similarly, the crowd which gathers to watch the unfolding events are described as one body; the crowd moves as one, as blood convulsing through the chambers of the heart, dispersing "with a single diastole-systole" (Beckett, Murphy 30). Uninviduated and obedient, invisible by virtue of their normativity, the crowd think, act, and move as one. In Foucauldian terms, as the conduct of their conduct is controlled by the civic guard, they are governed, organised, and regulated as one docile body.

According to Bixby: "In Murphy, the presence of the Civic Guard in the GPO means an effective end to such protests against the state and its representative icons. If the guard's noble proportions and "monstrous hand" register the power of the state, his inarticulacy betrays its failure to negotiate the terms of Irishness" ("GPO" 91). Bixby further elaborates that Neary's form of cultural engagement "signifies cultural difference from the minority position, indicating protest from the periphery of the national imagination against the privilege of invented tradition" ("GPO" 92). Bixby reads a postcolonial dimension to Neary's protest: a refusal to become docile, a refusal to be governed. And Neary's protest is diffused by Wylie's insistence to the guard that he is mad, that is, disabled. As Neary bucks the normative expectations of how citizens should behave, Wylie's pleas that he is impaired wrests him from violence; the guard is satisfied that Neary will be returned to the hospital and to medical surveillance and control. Here, the biopolitical power of the state turns against its citizens, epitomised by Wylie's claims that Neary is disabled: “John o' God's. Hundered per cent harmless. ... As quiet as a child" (Murphy 29; 30). As Shelley Tremain shows, "differences amongst populations have been materialised, made perceptible in pathology, while the subjects who come to bear them are rendered as defective, are disabled, and signified as less than fully human" (Tremain, "Bioethics" 102). Wylie offers to return Neary to "the cell", returning him to a state of silent docility.

Beckett's distrust of civic guards persisted past Murphy. In a letter from September 1937 to his friend Thomas MacGreevy, as he awaited prosecution for a dangerous driving offence, Beckett admitted: "There is no animal I loathe more profoundly than a Civic Guard, a symbol of Ireland with his official Gaelic loutish complacency" (Letters I 555). A recurring trope of his fiction is the encounter with an abrupt civic guard. Beckett's vagrants seek to exist outside of governed spaces, exemplifying a life outside of the norm, and of national protection and welfare. As Joseph Anderton writes, "[a]s people exiled and displaced from the governed space, Beckett's creatures illustrate the biopolitical threshold that appends passive neglect and active abuse" (124). In this context, Anderton reads Molloy as a reinterpretation of the Cuchulain myth involving state surveillance. Upon realising that Molloy is travelling sans-papiers, the sergeant who he encounters turns violent, threatening him with a "cylindrical ruler" when he discovers that Molloy is circulaire: "I had no papers in the sense this word had a sense for him, nor any occupation, nor any domicile" (Molloy 22). Suitably 
relegated to the outskirts of society, Molloy is threatened with a ruler: a weapon of standardization, normalization and governance. Anderton notes how Molloy mirrors Cuchulain: "I would take the place of the dog I killed, as it for her had taken the place of a child" (Molloy 46). Here, Molloy's subservience and dehumanisation retrace ideas of servitude and ownership from the original Cuchulain myth (Anderton 128).

The biopolitical impulses of many of Beckett's works far exceed the context of Ireland in the 1930s. Recent explorations of what we might deem Beckett's political motivations present a nuanced and rather more complex picture of the political nexus in which Beckett wrote. Indeed, the literature of the 1930s, previously an overlooked era of Beckett's writing, is currently enjoying a wealth of important revision about the complex nature of this body of work. Lloyd (Meadhbh) Houston's analysis of "Censorship in the Saorstat" is unconvinced of the ethical valour of and political subversion of the work, tracing instead a sectarian language of eugenics in the work. Similarly, Emilie Morin's Beckett's Political Imagination cautions against reading Beckett's work in order to "ventriloquise contemporary liberal values"; instead, Morin explores how Beckett's early body of work "ventriloquises competing idioms in Irish political culture, interrogating the narratives of political exclusion and disaffection" that commonly characterise discussions of Beckett's early writing (Morin 10;3).

The critical tendency to collapse contemporary values into Beckett's work, as Yael Levin has recently shown with regards to the field of disability studies, requires a tenacity of thought and attention to the minute detail of Beckett's works that must "take cognizance of an essential incongruity between a politically conscripted theoretical framework and aesthetic experimentation, between a mimetic fidelity to lived experience and an art of non-relation" (Levin 171). While the point about disability studies is a cogent one, the nature of this "essential incongruity" skirts the historical and political landscape in which Beckett writes, and the history of Irish literature to which Beckett responds. An apt reading of the uses of disability in Beckett demonstrates the ways in which power, surveillance and biopolitics push so many of Beckett's characters outside of the norm and into the literary landscape of his works. Beckett gets the biopolitical, recognises that it is only against the norms of the state that disability can be seen to manifest in the individual's body. As Thomas Jordan argues, able-bodiedness and citizenship go hand-in-hand: "the fact that so many Western nations have relied upon discourses of disability to produce exceptions to their laws only shows how deeply related the concept of able-bodiedness and citizenship are in the West" (3).

For Mitchell and Snyder, disability is an essential and foundational myth in the creation of any national identity: "one cannot narrate the story of a healthy body or national reform movement without the contrastive device of disability to bear out the symbolic potency of the message" ("Narrative Prosthesis" 234). In giving us disabled characters that are rejected and punished by society, or shunned and marginalised by their communities, Beckett shines a light upon the disenfranchising experience of disability. In relief, he also shows us the negative power of the state and the norms to which citizens are expected to adhere. Mitchell and Snyder explicitly connect their discussion of the disabled subject as contextualised by the subject's relationship to the state: radical disabled embodiment can "function as a disruptive force of resistance in sedimented systems of privilege accorded to normative bodies within nationalist imaginaries of ableism" (Biopolitics 7).

In the brushes with civic authority, we see something of the radical potential of disabled bodies to challenge established biopolitical norms. Beckett's hostility for what Corkery identified as the "national" and the "normal". The biopower of the state, wielded in the figure of the civil guard focuses the narrative gaze disables the character, revealing Neary and Molloy's supposed illegitimacy, stripping them of state protection and revealing their bodily vulnerability. These acts of surveillance, narrowed, detailed and even cruel accounts of embodiment and impairment, echo the pointed criticism of his early essays and highlights the 
contingency and outrageous precarity of state-sanctioned legitimacy. In depicting the processes of power upon the bodies of his characters, Beckett negotiates a fuller understanding of disability and impairment that also undermines contemporaneous notions of "national" and "normal" literature.

In this essay, I argue that Beckett demonstrates a profound distrust of the biopolitics of the Irish Free State. I situate Beckett's depiction of the hero Cuchulain in two brief examples from the beginning of his literary career in order to interrogate how disability and compulsory able-bodiedness are foundational myths for the Irish Free State. Taking the interpolation of disability in biopolitics, I examine the normalising impulses in revivalist literature and criticism, exemplified by Lady Gregory, Standish O'Grady, W.B. Yeats and Daniel Corkery. Against this normalising, nationalising literature, I situate Beckett's satirical renderings of Cuchulain as evidence of a profound discomfort and frustration with the biopolitical mechanisms of governance in the newly-founded Irish State. In two significant texts from the 1930s, "Censorship and the Saorstat" and Murphy, Beckett reveals a deep-seated cynicism towards the revivalist project and its ableist impulses. In these works, Beckett undermines State evocation of Cuchulain as a mythical projection of health, heroism, fitness and strength. Indeed, in Murphy, Beckett's interrogation of Cuchulain as a national figure reveals the disabling apparatus in which his characters operate, situating the literary resurrection of the figure as an act of state governance. In so doing, Beckett responds to Yeats' depiction of Cuchulain and the troubling depiction of disability in those works. By contrast, Beckett's works demonstrate the paradoxes and non-sequitur of the adoption of Cuchulain as a national figure in the foundational acts of the Irish State.

\section{Works Cited}

Anderton, Joseph. Beckett's Creatures: Art of Failure after the Holocaust. Bloomsbury: London, 2016.

Beckett, Samuel. "Censorship and the Saorstat". Disjecta: Miscellaneous Writings and a Dramatic Fragment. Ed. Ruby Cohn. New York: Grove, 1984. 84-88.

. "Che Sciagura." TCD Miscellany (November 1929): 42.

. Disjecta: Miscellaneous Writings and a Dramatic Fragment. Ed. Ruby Cohn. New York: Grove, 1984.

. The Letters of Samuel Beckett: Volume 1; 1929-1940. Ed. Martha Dow Fehsenfeld and Lois More Overbeck. Cambridge: Cambridge University Press, 2009. Molloy. London: Faber \& Faber, 2009.

Murphy. Ed. J. C. C. Mays. London: Faber \& Faber, 2012.

. "Recent Irish Poetry". Disjecta: Miscellaneous Writings and a Dramatic Fragment. Ed. Ruby Cohn. New York: Grove, 1984. 70-76.

Bixby, Patrick. "Beckett at the GPO: Murphy, Ireland, and the "unhomely"'. Beckett and Ireland. Ed. Seán Kennedy. Cambridge: Cambridge University Press, 2010. 78-95.

—. "Cuc[h]ulain in Bronze: The Afterlife of a Republican Icon". Standish O'Grady's Cuculain: A Critical Edition. Eds. Gregory Castle and Patrick Bixby. New York: Syracuse University Press, 2016. 241-257.

Censorship of Publications Act, 1929.

Corkery, Daniel. "On Anglo-Irish Literature." Synge and Anglo-Irish Literature. Cork: Mercier Press, 1996. 
Davidson, Michael. “'Every man his specialty': Beckett, Disability, and Dependence." Journal of Literary Disability 1.2 (2007): 55-68.

Foucault, Michel. The Birth of Biopolitics: Lectures at the Collège de France, 1978-9. Ed. Michael Sennellart. London: Palgrave Macmillan: 2008.

-. "Society Must Be Defended": Lectures at the Collège de France, 1975-76. Ed. Mauro Bertani and Alessandro Fontana. New York, Picador: 2003.

- Discipline and Punish: The Birth of the Prison. New York: Random House, 1995.

Greene, David H. and Edward M. Stephens. J. M. Synge, 1871-1909. New York, Macmillan: 1959.

Gregory, Lady Augusta. Cuchulain of Muirthemne: The Story of the Men of The Red Branch of Ulster Arranged and Put into English by Lady Gregory with a Preface by W.B. Yeats. London: John Murray, 1911.

Gregory, Lady Augusta and W. B. Yeats. Cathleen Ni Houlihan. The Collected Plays of W.B. Yeats. London: Macmillan \& Co., 1960.

Harrington, John. The Irish Beckett. Syracuse, New York: Syracuse UP, 1991.

- On the Boiler. The Collected Works of W. B. Yeats Vol. V: Later Essays. Eds. Elizabeth Bergmann Loizeaux and William H. O'Donnell. New York: Scribners, 1994. 220-251.

Houston, Lloyd (Meadhbh). "“'Sterilization of the Mind and Apotheosis of the Litter': Beckett, Censorship, and Fertility." The Review of English Studies 69.290 (2018): 546564.

Kennedy, Sean. “Too Absolute and Ireland Haunted': MacGreevy, Beckett and the Catholic Irish nation". The Life and Work of Thomas MacGreevy: A Critical Reappraisal. Ed. Susan Schreibman. London: Continuum Press, 2013. 189-202.

Kiberd. Declan. “On Baile's Strand: W. B. Yeats' National Epic.” The Princeton University Library Chronicle 68.1/2 (2007): 261-270.

Levin, Yael. "Univocity, Exhaustion and Failing Better: Reading Beckett with Disability Studies". Journal of Beckett Studies 27.3 (2018): 157-174.

Jordan, Thomas. "Disability, Able-bodiedness, and the Biopolitical Imagination". Review of Disability Studies: An International Journal 9.1 (2014): 26-38.

McRuer, Robert. Crip Theory: Cultural Signs of Queerness and Disability. New York and London: New York University Press, 2006. 222-235.

Mitchell, David T. and Sharon L. Snyder. "Narrative Prosthesis and the Materiality of Metaphor". The Disability Studies Reader. Fourth Edition. Ed. Lennard J. Davis. New York: Routledge, 2013. 205-216.

- The Biopolitics of Disability: Neoliberalism, Ablenationalism and Peripheral Embodiment. Michigan: University of Michigan Press, 2015.

Morin, Emilie. Beckett's Political Imagination. Cambridge: Cambridge University Press, 2017.

Pearse, Patrick. "Seanmóir." An Claidheamh Soluis. $27^{\text {th }}$ October 1906.

Quirici, Marion. "Cathleen ni Houlihan and the Disability Aesthetics of Irish National Culture". Éire-Ireland 50.3/4 (2015): 74-93.

Saltes, Natasha. "'Abnormal' Bodies on the Borders of Inclusion: Biopolitics and the Paradox of Disability Surveillance”. Surveillance and Society 11.1/2 (2013): 55-73.

The Táin: From the Irish epic Táin Bó Cuailnge. Trans. Thomas Kinsella. Illustrations by Louis le Brocquy. Oxford and New York: Oxford University Press, 1969.

Tremain, Shelley, ed. "Introduction". Foucault and the Government of Disability. Ann Arbor: University of Michigan Press, 2005: 1-25.

. "The Biopolitics of Bioethics and Disability". Bioethical Inquiry 5 (2008): 101-106. 
Valente, Joseph. The Myth of Manliness in Irish National Culture, 1880-1922. Urbana, Chicago, and Springfield: University of Illinois Press, 2011.

Yeats, W.B. "Preface". Cuchulain of Muirthemne: The Story of the Men of The Red Branch of Ulster Arranged and Put into English by Lady Gregory with a Preface by W.B. Yeats, by Lady Augusta Gregory. London: John Murray, 1911. vii-xvii.

. The Collected Plays of W. B. Yeats. London: Macmillan \& Co., 1960.

On Baile's Strand: Manuscript Materials. Eds. Jared Curtis and Declan Kiely. New York: Cornell University Press, 2014.

Siobhán Purcell's research primarily focuses on representations of disability, impairment and decadence in Irish literature. In 2016 she completed her Irish Research Council-funded PhD thesis on the subject of disability in Beckett's prose, poetry, and translations (1928-1945). Her work has been published in Samuel Beckett Today/Aujourd'hui, Breac, Dublin James Joyce Journal and the James Joyce Literary Supplement. She is currently expanding her research to include a number of Irish authors. In addition to present work on Samuel Beckett, she has forthcoming articles on James Joyce, Brian O’Nolan, Lucia Joyce, and Lynda Radley.

siobhanmpurcell@gmail.com 